\title{
Revenue, welfare and trade effects of European Union Free Trade Agreement on South Africa
}

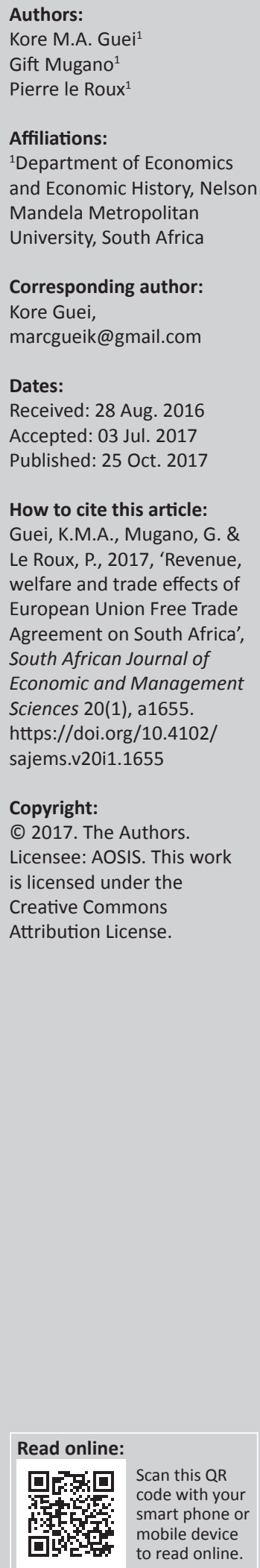

Background: Using the partial equilibrium WITS-SMART Simulation model to assess the impact of liberalisation under the Trade Development and Cooperation Agreement (TDCA) of a free trade area between the European Union and South Africa. The identification of the impact of such agreement allows for trade policy negotiation adjustment that can be beneficial for South Africa.

Aim: The aim of the study is to estimate and discuss the impact of a Free Trade Agreement (FTA) with the European Union and South Africa. More specifically, the study intends to estimate the impact of revenue, welfare, imports, exports, trade creation and to come up with policies options for South Africa that can be used in negotiations and policy formulations.

Setting: The study used international trade data (2012) available in the WITS-SMART model to assess bilateral trade agreement between the European Union and South Africa.

Methods: To identify the impact on revenue, welfare, imports, exports and trade creation, the study simulated an FTA ( $0 \%$ tariff rate) for all goods exchanged between the European Union and South Africa. Also, the elasticity of substitution used for the simulation model was 99\%.

Results: The findings of the study reveal that total trade effects in South Africa are likely to surge by US\$ 1.036 billion with a total welfare valued at US\$ 134 million. Dismantling tariffs on all European Union (EU) goods would be beneficial to consumers through net trade creation. Total trade creation would be US\$ 782 million. However, South African producers are likely to contribute a trade diversion of US\$ 254 million which has a negative impact on consumer welfare. The country might also experience a revenue loss amounting to US\$ 562 million because of the removal of tariffs. In trade, the country's exports and imports to the EU are expected to increase by US\$ 12.419 million and US\$ 1.266 million, respectively.

Conclusion: The European Union-South Africa FTA would result in both trade creation and trade expansion effects. However, trade creation and revenue loss are potential threats. In order to mitigate revenue loss, government needs to consider alternative tax such as consumption tax on certain goods and value-added tax.

\section{Introduction}

South Africa embarked on a Trade Development and Cooperation Agreement (TDCA) with the European Union (EU) in October 1999, which came into effect in 2004 (European Commission Act 2004). The TDCA established preferential trade arrangements between the EU and South Africa with the progressive introduction of a free trade area. This occurred because there was a general belief that lifting trade barriers would contribute to economic growth and create jobs. The European Commission believed that bilateral Free Trade Agreement (FTA) with its key partners would be mutually beneficial and reinforce competitiveness. The treaty consists of three areas of agreement. It includes the FTA between the EU and South Africa. It includes development aid as well as several areas of cooperation such as economic and social cooperation. The agreement provides for the liberalisation of 95\% of the EU's imports from South Africa within 10 years and $86 \%$ of South Africa's imports from the EU in 12 years (European Commission Act 2004).

The South African Department of Trade and Industry (DTI) revealed that the EU is South Africa's main trading and investment partner (European Commission Council 2006). The free trade area aims to ensure better access to the community market for South Africa and access to the South African market for the EU. This plays an important role in integrating South Africa into the world economy. The agreement sets out detailed rules of origin to ensure that products benefitting from the preferential arrangement come only from South Africa or the EU. It also aims to avoid misuse by firms with a dominant position in the market, thus ensuring free competition among 
the companies from the EU and South Africa. The agreement also allows South Africa and the EU to adopt safeguard measures when an imported product threatens to cause serious injury to the national industry. South Africa may adopt transitional safeguard measures (e.g. by increasing customs duties). In 2016, the International Monetary Fund (IMF) estimated gross domestic product (GDP) in South Africa to be US\$ 315 billion with an unemployment rate of $25.4 \%$. The World Bank revealed that South Africa's exports of goods and services were last estimated at 30.6\% of GDP in 2016.

Since democracy in 1994, South Africa has opened up its economy, and trade quotas and tariffs have decreased considerably; however, the gains from conventional trade liberalisation for an economy like South Africa are moderate at best. During the last decade, South Africa has undergone several changes. The primary sector which comprises agriculture, forestry and fishing, as well as mining, has collectively maintained their share of GDP over time, amounting to $11.8 \%$. Since 1994 , the share of the secondary sector has decreased continuously from $27.7 \%$ to $19 \%$ in 2012. From 1994 to 2012, there has however been a significant expansion of the tertiary sector from $12 \%$ to $22 \%$ (Industrial Development Corporation 2013).

The rapid growth of the tertiary sector, which includes trade and transport, and other business services can be attributed to the multilateral reduction in tariffs and subsidies through the country's World Trade Organization commitment (DTI 2014). The TDCA establishes preferential trade agreements as well as the progressive introduction of a free trade area. According to South Africa's DTI, the scheduled liberalisation entered into force in May 2004 and was to be completed by 2012 (Department of Foreign Affairs 2009). This study therefore seeks to analyse the impact of an FTA between the EU and South Africa, assuming full liberalisation during the year 2012.

Trade liberalisation presents a serious challenge to South Africa as the country already expects a budget deficit of $3.4 \%$ for the year 2016/2017 (Department of National Treasury 2017a). The DTI reveals that the EU offered to liberalise 95\% of its duties on South African-originating products by 2010, and South Africa, in turn, offered to liberalise $86 \%$ of its duties on products originating from the EU. This, therefore, means that in the event of an FTA, only $14 \%$ of the EU products would be subject to import duty. This would have a negative effect on revenues and the competitiveness of local industries. The simple mean applied tariff rate for all products in South Africa is at 4.2\% (World Bank 2015). An FTA with the EU would affect competitiveness of South African exports as the inputs acquired outside the FTA would be acquired at a higher price. Trade liberalisation would therefore not only pose a threat to import revenue but could also result in the closure of local industries. Notwithstanding these adverse effects of liberalisation, South Africa has continued to liberalise substantially over the last decade and has played a leadership role in the current Doha Round of negotiations.
In the light of the above discussion, a research question has emerged: Has trade liberalisation led to trade creation in South Africa? Has trade liberalisation led to welfare gain? Has trade liberalisation led to an increase in imports? Has trade liberalisation led to an increase in exports? Has trade liberalisation led to a loss of revenue for South Africa?

The purpose of this study is to estimate and discuss the impact of an FTA with the EU and South Africa. Specifically, the study intends to:

- examine the revenue and welfare implications of the EUSouth Africa FTA (EU-SA FTA) on South Africa

- examine the impact of the EU-SA FTA on South Africa's imports and exports

- examine the impact of the EU-SA FTA on trade creation in South Africa

- to come up with policies options for South Africa that can be used in negotiations and policy formulations.

\section{Literature review}

This section reviews the literature on the different economic integration and specifically trade expansion effects, as well as the revenue implications of an FTA. The assessment shall be based on both theoretical and empirical literature.

\section{Economic integration}

Economic integration is a process in which two or more states in a broadly defined geographic area reduce a range of trade barriers to advance or to protect a set of economic goals. From a political point of view, economic integration differs from the broader idea of regionalism in general. The aim of the economic integration is to reduce costs for both producers and consumers and to increase trade between the countries taking part in the agreement (Burges 2007). Economic integration helps to reduce and ultimately remove tariff and nontariff barriers to the free flow of goods, services, capital and labour. There are four main types of economic integration.

A preferential trade agreement is a trade pact between countries that reduce tariffs for certain products and the countries who signed the agreement. The new tariffs set are not necessarily eliminated but they are lower than those countries that are not part of the agreement. Preferential trade agreements offer additional benefits such as increased foreign benefit, and other positive externalities (Baldwin 2011).

A free trade area represents an economic bloc in which all barriers to trade are abolished among member countries, but each member maintains its own independent external trade barriers beyond the bloc. The FTA as opposed to the custom union does not specify the external tariffs of all signatories contractually (McLaren 2004).

The third form of economic integration is a custom union. It allows free trade among its members and adopts a common external tariff (CET) against countries outside the 
custom union (Peters 1979). Unlike the common market, it does not allow free movement of capital and labour among member countries.

The economic union is the most advanced type of economic integration. It is a common market involving more than one nation based on a mutual agreement to permit the free movement of capital and labour. It also requires the coordination of various social, fiscal and monetary policies among participating nations. Trade liberalisation may result in static and dynamic benefits.

\section{Static and dynamic benefit of a Free Trade Agreement}

In terms of static and dynamic benefits, the FTA leaves future external trade policy to the discretion of each member government, thus providing a continual incentive for interest groups to try to influence the government (Mclaren 2004). The impact of the EU-South Africa FTA is of a more dynamic nature in terms of increased imports and exports competition. Secondly, Tsolo (2010) in their study state that the agreement could lead to a substantial reduction in revenue as a direct outcome of tariff reductions. The reason for this would be because the CET that was applied before the agreement has been removed. Trade liberalisation may also result in revenue loss and welfare gain.

\section{Revenue and welfare effect of Free Trade Agreement}

The free trade area is generally seen as welfare creation and revenue loss as a result of the removal of tariffs. It is important to note the revenue loss relates to import tariff revenues. The belief exists that free trade will maximise world welfare. Free trade increases imports and exports through trade creation. However, as long as these countries have indirect taxes such as value-added tax (VAT), the shortfall in revenue would taper off (Lang 2006). Aggregate welfare of a free trade area is just the sum of effects across countries.

Free trade area creates both trade creation and trade diversion. Trade creation occurs when trade increases. However, trade diversion occurs when an FTA shifts imports from a more efficient supplier to a less efficient supplier, which in itself causes a reduction in national welfare. National welfare gains occur when trade creation outweighs trade diversion. Thus, a country would only enter an FTA if the FTA is welfare improving (Suranovic 1997). This happens when trade creation outweighs trade diversion. The market with trade creation would generate national welfare gains, while the market with trade diversion would generate national welfare losses. However, it is also possible for trade diversion to outweigh trade creation. This is welfare reducing. This is quite interesting because it suggests that free trade could also reduce the national welfare of the countries involved. The only way to prevent this is to ensure that all barriers to trade against all countries are removed. This would reduce trade diversion.

\section{The European Union and South Africa Free Trade Agreement}

When South Africa became a democracy in 1994, the government applied for a membership in the Lome Convention in order to have access to the beneficial trade contract. The EU realised that trade with South Africa was important and a free market would benefit both of them. Hence, in 1996, the EU and South Africa began a discussion on creating a new trade and development collaboration. The collaboration's objective was to increase and improve the trade condition between the two parties.

In 1999, they signed the 'Trade Development and Cooperation Agreement' (TDCA). The implementation date of the agreement was set on 01 January 2000. The government of South Africa viewed the TDCA as a sign of further development and more integration. The TDCA contracts consist of two parts. The EU-SA FTA and the European Program for Reconstruction and Development (EPRD).

The aim of the EU-SA FTA is to gradually increase the amount of duty-free agricultural and industrial products in each market. The agreement is asymmetric in terms of time frame and commodity coverage. The EU has a period of 10 years to fully implement the agreement, while South Africa has a period of 12 years. The different time frames and commodities are supposed to make the agreement fair to both parties.

Figure 1 describes the trends in trade between the EU and South Africa from 2001 to 2014. This shows that South Africa has experienced a considerable increase in its exports to the EU since 2001. After 2012, South Africa's exports to the EU is still rising even though the increase is not significant as it is shown in Figure 1. This can be explained by the fact that the liberalisation process has reached its final stage.

\section{Strategies to mitigate revenue loss from a Free Trade Agreement}

The government of South Africa will have to reduce the overall tax burden because of trade liberalisation. This requires the adoption of compensated revenue to offset any loss of trade tax revenue. This section highlights some recommendations to the government of South Africa in order to reduce the revenue loss associated with a FTA.

In terms of fiscal implication for South Africa, a first policy advice will be the shift away from trade tax towards other forms of taxation such as income and sales tax. In fact, the need to offset revenue losses from trade liberalisation by strengthening domestic taxation has been a key consideration in the adoption of VAT (IMF 2003). The recommendation to move away from trade tax towards domestic consumption and income tax reflects the view that trade taxes are a relatively inefficient way of raising revenue. Indirect taxes, which shift the overall taxation burden from factor of production (capital and labour) to consumption, are believed to be associated with superior employment. 


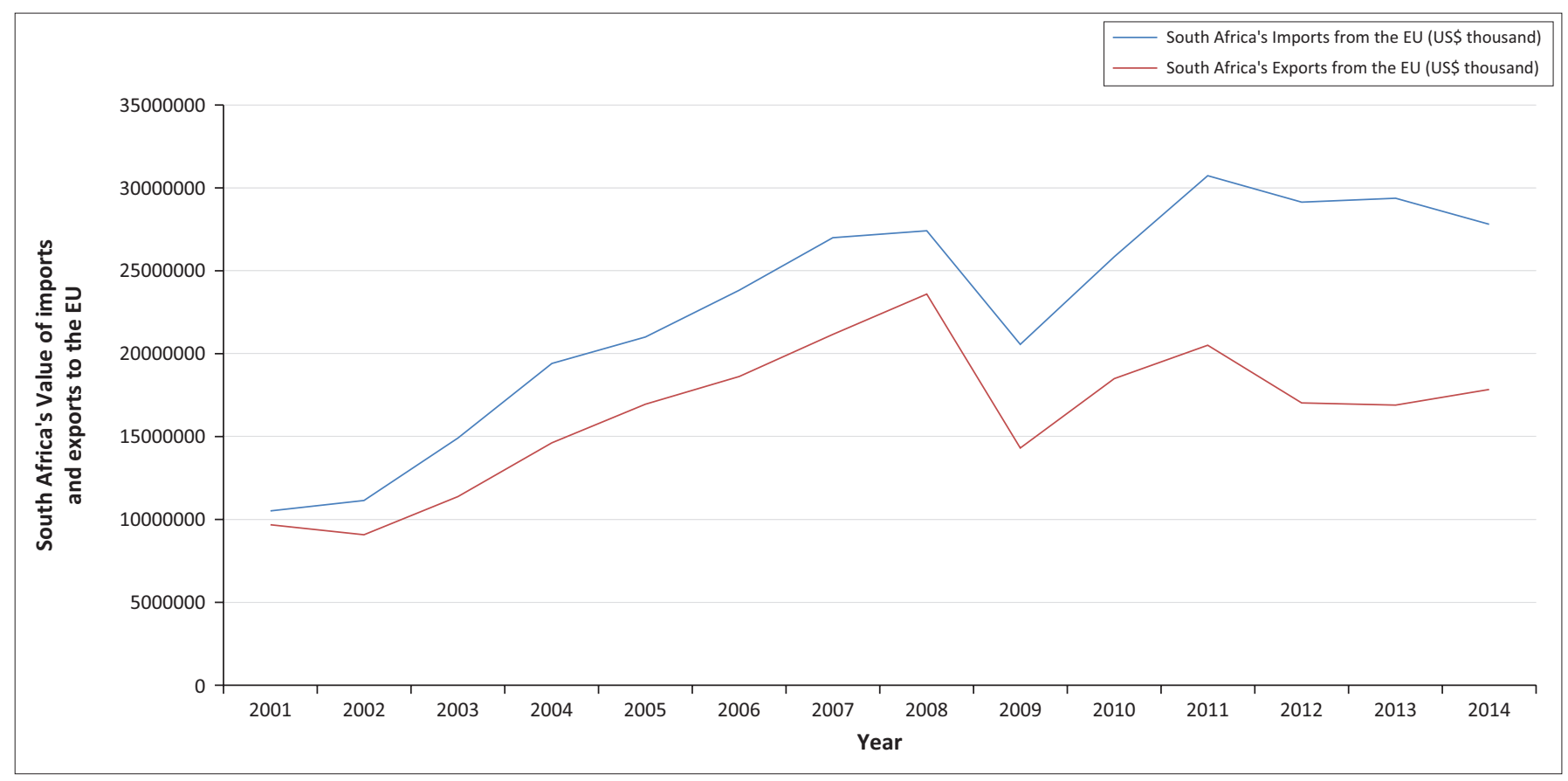

FIGURE 1: South Africa's Value of imports and exports to the EU (2001-2014).

In terms of personal income, there is the need for South Africa to look for opportunities to broaden the tax base. South Africa can improve its tax base by adopting the resident and ordinarily resident rules of the Indian tax system. This means that residents and ordinarily residents in South Africa will be taxed based on their worldwide income.

South Africa can also consider increasing the property taxes. This can be done by including the annual value of house property in income as it is done under Indian legislation. The country can also allow certain deductions against the annual value of house property to maintain a fair tax system.

Exemptions and deductions remain significant in South Africa, hence the government may consider disregarding the employment abroad exemption or the foreign pension exemption. Furthermore, the government can allow for the deduction of interest payments on loan for higher education. These measures would help improve revenue collection and offset the losses associated with the tariff cut.

In the financial sector, the government should adopt a financial activities tax (FAT), which is a tax on the sum of wages and profits of financial institutions. This would provide a fair and substantial contribution of financial institution to the fiscal revenue (IMF 2011). The FAT will serve to counteract the VAT exemption for financial services.

Another avenue for South Africa to reduce the loss in its tariff revenue is by identifying and acting on compliance gaps. The improvement of the compliance gap would promote fairness and reduce distortion. This can be done by addressing offshore tax abuse. This measure would discourage volatile financing.

\section{Empirical literature}

The United States International Trade Commission (2017) looked at the likely impact of the Trans-Pacific Partnership (TPP) Agreement on the United States. The findings suggest that the TPP has a positive impact on the United States although it is a small percentage of the overall size of the economy. The United States exports and imports will be US\$ 27.2 billion (1\%) and US\$ 48.9 billion (1.1\%) higher, respectively. The commission estimates that the TPP will harmonise regulations, increase certainty and decrease trade costs for firms that trade and invest in the TPP regions.

Another study in the United States by Abdelmalki, Sandretto and Jallab (2007) assesses the FTA between the US and Morocco using the WITS-SMART Simulation Model. The findings showed that the FTA significantly reduced Moroccan tariff by more than US $\$ 147$ million. Almost $60 \%$ of this loss resulted from the elimination of duties on the imports of US cereals. Cereals represented $0.5 \%$ of GDP and $4.5 \%$ of the balance of payments. Cereals accounted for almost $60 \%$ of revenue shortfall. This explains why this product was treated separately during the negotiations. The findings also show that consumer surplus was mainly improved by lowering the price of industrial goods. The partial equilibrium revealed that imports from the United States to Morocco increased by US\$ 53.68 million.

In America, Villa, Gomez and Omar (2012) used trade data for 2010 and applied ex-ante partial equilibrium modelling to calculate the impact of the preferential trade agreement between Canada and Colombia. The simulations carried out showed that trade creation could be one and a half times larger than trade diversion. Trade between the two countries in the first year grew by approximately $10 \%$. Use of the WITS-SMART Model showed that though Canadian tariff revenue fell by US\$ 78.1 million, Canadian consumer welfare improved by US $\$ 11.5$ million. 
In the EU, Elebehri and Hertel (2004) have compared the potential impacts on Morocco's welfare, production and trade, from implementing the Morocco-EU-FTA. The analysis pays special attention to several key structural features of the Moroccan economy. The results show that the FTA with the EU generates a welfare loss for Morocco as most of the manufacturing sectors contract under the FTA and only few export-oriented sectors, such as clothing, expand production. Hence, it appears that the main effect of FTA with the EU is to lock the Moroccan manufacturing sector even more firmly into its current pattern of specialisation.

Lang (2006) also looked at the impact of the full liberalisation of imports from the EU to the Economic Community of Western African States (ECOWAS) using the partial equilibrium smart model. The result showed that trade creation by far outweighs trade diversion. Total EU exports to the ECOWAS surged by US $\$ 1.8$ billion, with France and United Kingdom making the largest profits. However, more than US\$ 365 million was diverted in favour of less efficient EU producers. Tariff revenues were reduced by the agreement. For example, Guinea-Bissau and Ghana lost approximately 19\% of their budget revenues.

In Asia, Choudhry, Kalumnal and Varma (2013) evaluated the impact of Sri Lanka's FTA using a sector-specific analysis of the textile and clothing sector. Sri Lanka provided reduction in tariffs - 35\% in 2003, 70\% in 2006 and 100\% in 2008. The result of the SMART analysis revealed that Indian exports of textile to Sri Lanka increased from US\$121 million to US\$ 395 million during the period 1999-2009. Trade creation effects dominate trade diversion effects. For example, when articles of apparel and clothing accessories were traded, trade creation was around US\$ 555000 and trade diversion was around US\$248 000.

Turning to Africa, Othieno and Shinyekwa (2011) in their study investigated the effects of the East African Community Customs Union Principle of Asymmetry on Uganda with regard to trade, welfare and revenue effect since 2005. The end of tariff reduction increased trade creation and welfare effects. This effect was reflected in consumer surplus in terms of reduced prices. Tariff reduction implies government revenue loss. In addition, the diversion effect that resulted from the CET on respective products such as woven cotton fabric, soap products and paints vanished. Inefficient producers within the union could equally have been displaced by building specialised capacity in the sectors.

Mugano, Brookes and Le Roux (2013) conducted a study on the impact of a South African Development Community (SADC) Customs Union on Zimbabwe. The WITS-SMART Model was used for the study. The findings reported that trade expansion valued at US\$ 39 million and consumer welfare at US\$ 7 million. In trade, Zimbabwe's exports were expected to fall by $0.94 \%$, while imports were expected to surge by $2.05 \%$. However, the country lost revenue amounting to US\$ 42 million.
The results obtained varied from one case study to another. The implication of an FTA between two countries depends on a number of factors.

From the literature, it is not possible to discern the impact of an FTA on imports, exports, trade creation, trade diversion and revenue and consumer surplus. The empirical review, however, does help to identify the possible outcomes of an FTA. However, it does not allow one to draw a general conclusion about any FTA. Thus, the EU-South Africa FTA remains an empirical question that needs to be addressed in order to determine whether it is welfare increasing or decreasing.

A recent study by Kwaramba, Kwenda-Magejo and Rankin (2015) examined the EU and South Africa FTA and export trade margins. Their study used a different way of measuring trade margins at the product-, country- and product-country levels. Their results show that tariff reductions had a constantly positive impact across products at the intensive margin.

Studies conducted by Assarson (2005) on the impact of South Africa and the EU-FTA support the view that EU-SA FTA stimulated both exports and imports. The analysis conducted compared the trade statistics between the years 1999 and 2004. Their results indicate that South Africa benefits from the agreement in terms of improved trade.

Tsolo (2010) looked at the South Africa and EU TDCA. Their results indicate that the volume of exports and imports to South Africa from Botswana, Lesotho, Namibia and Swaziland (BLNS) will increase following the agreement. This shows that the EU-SA TDCA has benefitted the BLNS countries by boosting their exports.

Efforts still have to be made by both the EU and South Africa for the agreement to be fully implemented. Previous studies undertaken by Assarson (2005) and Tsolo (2010) on the implication of the EU-FTA on South Africa used trade statistics and time-series cross-sectional data to determine the impact of the EU-FTA on South Africa. These studies did not analyse the potential impact such an agreement would have on trade creation, trade diversion, and welfare and revenue effects. This study (by means of the WITS-SMART Model) would, therefore, fill the gap by analysing the potential impact such an agreement if fully implemented in 2012 would have on South Africa. The WITS-SMART Model is a partial equilibrium model (PEM) developed by the United Nations Conference on Trade and Development (UNCTAD) during the 1980s mainly to assess the impact of the General Agreement on Tariffs and Trade (GATT) rounds. The WITS-SMART Model gives the possibility to approximate the consumer surplus.

\section{Model framework}

The study used the PEM to investigate the impact of the EUSouth Africa FTA on South Africa. The focus was on exports, imports, trade creation, trade diversion, welfare and tariff 
revenue. The figures used in the simulation were for the year 2012. The PEM was chosen over the general equilibrium (GE) model because PEMs provide results at a more disaggregated level (HS-6 in this study). The PEM enables the calculation of direct trade effects (trade creation and trade diversion effects). The WITS-SMART Model was developed by the World Bank and the UNCTAD. It employs tariff data from the Trade Analysis and Information Systems (TRAINS) and the World Trade Organization integrated database (IDBWTO) and consolidated tariff schedule (CTS-WTO). TRAINS has an advantage in that it uses harmonised schedule nomenclature and includes data from 1988. The CTS-WTO contains binding tariffs, which are useful when commenting on the negotiated tariff schedules (Villa et al. 2012).

PEM may be sensitive to the elasticity parameters used and ignore interactions with other markets, although interaction can be modelled in PEM (Mkenda \& Hangi 2009). In this study, three different elasticity scenarios were used to compensate for these shortcomings and to gauge the effects on the simulations.

Milner, Morrissey and McKay (2005) provide a simple analytical framework explaining the theory behind partial equilibrium modelling. Despite its shortcomings, a partial equilibrium framework is more suitable as it allows the utilisation of widely available trade data at the appropriate level of detail to capture the principle of special and differential treatment in the simulation analysis.

This study simulated the welfare and revenue effects resulting from the FTA. The welfare effect is related to the consumer surplus. However, because government revenue tends to decline with the reduction in tariffs and rise when imports increase, the net welfare effect needs to be carefully addressed. PEM is static in nature, allowing only for comparative static comparison (Lang 2006). However, the focus of this study is on the static effect of the EU-South Africa FTA agreement on South Africa. Hence, the WITS/SMART model emerged as the best choice not only because of the static effect but also because of its strength in analysing the tariff effect of a single market on disaggregated product lines.

\section{Sensitivity analysis and robustness tests}

For the purpose of this study, one scenario is defined to represent a magnanimous release by the South African market to EU imports. These findings would not necessarily be the exact outcome of the FTA. Analysing the impact of full liberalisation using the partial equilibrium framework allows one to distinguish the products and sectors where the impact is greatest.

Identifying the products for which the impact of liberalisation is greatest may help South Africa to define their most sensitive products from which they may want to benefit by receiving a special and differentiated treatment. The sensitivity parameters analysed here are trade diversion and revenue loss. The elasticity of supply is considered infinite as much as the market partners perform as price-takers, and changes in demand are met with adjustments in quantities. The value considered for the elasticity of substitution, which determines the degree of substitution between different varieties of goods, according to the exports partner is 1.5 for each product or item.

Hence, this study applies a $100 \%$ tariff reduction to all products at the HS-6 level for the year 2012.

The SMART model can be solved either with perfectly elastic export supply, as when world prices of each variety are given, or by assuming upward-sloping export supply curves. The SMART model incorporates three types of elasticity.

Firstly, when import substitution elasticities record the rate of substitution between two goods with different origins. The Armington assumption is incorporated in the SMART model, meaning that similar goods from different countries are imperfectly substitutable. In SMART, the import substitution elasticity is considered to be 1.5 for each good.

Secondly, when the supply elasticities are deemed to be infinite (=99), which means that an increase in demand for a given good will always be matched by the producers and exporters of that good without any impact on the price of the good. This assumption is reasonably realistic when the importer (South Africa) is a small market and the exporter (the EU) consists of large industrialised economies.

Thirdly, when import demand elasticity measures the demand response to a shift in import price. Stern, Francis and Bruce (1976) revealed that in SMART analysis, the import demand elasticity varies at the HS-6 level.

The study used the elasticities in the base case scenario to evaluate the effects of the South Africa EU-FTA and then used the lower-, upper- and worst case scenarios to evaluate the robustness of the results (Table 1 ).

\section{Research findings}

This section presents findings from the study. The SMART model simulation analyses the EU-South Africa FTA impact on trade creation, trade diversion, trade diversion, exports, imports, and revenue and welfare effects. Table 2 shows trade creation and trade diversion effects of the EU-FTA on SA.

\section{Trade creation and trade diversion}

In standard analysis, when countries decide to embark on an FTA, trade creation occurs when the removal of tariffs changes the prices of imported goods, such that less efficient

TABLE 1: Elasticities used in sensitivity analysis.

\begin{tabular}{lllll}
\hline Elasticities & Lower bound & Base case & Upper bound & Worst case \\
\hline Substitution & 0.5 & 1.44 & 2 & 6 \\
Export supply & 89.1 & 99 & $99 \dagger$ & $99 \dagger$ \\
Import demand & 2.7 & 1.5 & 3.3 & 6 \\
\hline
\end{tabular}

$\dagger$, Retained as it is infinite. 
domestic production is replaced by imports from members of the free trade area whose products are now cheaper with the tariffs removal. Milner et al. (2005) explain, 'Trade creation usually describes the displacement of less efficient home production by globally efficient extra-regional production'. In the case of South Africa, it means that more efficient producers from the EU countries would displace the less efficient producers in South Africa and consumers would therefore benefit from lower prices.

Trade diversion occurs after the formation of a free trade area, the elimination of tariffs leads to a substitution of goods from countries that are not part of the free trade area but are more efficient than the goods from countries that form the free trade area. Milner et al. (2005) state, 'Trade diversion usually relates to diverting trade from more efficient extraregional suppliers to less efficient intra- regional suppliers'. Trade diversion would be costly for South Africa as revenue that would have been generated from imports from outside the EU is forgone and the products become more expensive because they would be sourced from higher-cost producers.

The FTA is expected to create a total trade effect of US\$ 1.035 billion in South Africa from the EU member states. Trade creation which is $75.44 \%$ of the total trade effect is expected to outweigh trade diversion which is just $24.55 \%$ of the total trade effect. Thus, the EU-South Africa FTA would have a positive total trade effect. This would be welfare improving for South Africa because consumers of the imports whose prices fall would enjoy the goods at a lower cost. These findings are in line with the research of (Abdelmalki et al. 2007) on the impact of FTA between the US and Morocco. In this case, the agreement led to a total welfare gain by Moroccan consumers because they had access to goods at lower prices. Table 3 shows the top 10 products with highest trade creation in South Africa.

TABLE 2: Trade creation and trade diversion effects of the European Union Free Trade Agreement on South Africa (US\$ 000).

\begin{tabular}{llll}
\hline Trading partner & Trade creation & Trade diversion & Trade effects \\
\hline European Union & 781606.42 & 254391.40 & 1035.997 \\
\hline
\end{tabular}

TABLE 3: Top 10 products with highest trade creation effects on South Africa (US\$ 000).

\begin{tabular}{|c|c|c|c|}
\hline HS-6 & Description & Total trade effect & Trade creation \\
\hline 870332 & $\begin{array}{l}\text { Other vehicles, of a cylinder } \\
\text { capacity exceeding } 1500 \mathrm{cc} \text { but } \\
\text { not exceeding } 2500 \mathrm{cc}\end{array}$ & 619,359 & 598,208 \\
\hline 870323 & $\begin{array}{l}\text { Of a cylinder capacity exceeding } \\
1500 \mathrm{cc} \text { but not exceeding } 3000 \mathrm{cc}\end{array}$ & 108,923 & 59,427 \\
\hline 870333 & $\begin{array}{l}\text { Of a cylinder capacity exceeding } \\
2500 \mathrm{cc}\end{array}$ & 10,042 & 6,518 \\
\hline 271012 & Light oils and preparations & 17,905 & 6,100 \\
\hline 870324 & $\begin{array}{l}\text { Of a cylinder capacity exceeding } \\
3000 \text { cc }\end{array}$ & 7,823 & 4,597 \\
\hline 570320 & $\begin{array}{l}\text { Tramway of a cylinder capacity } \\
\text { exceeding } 1500 \text { cc but Less than } \\
3000 \mathrm{cc}\end{array}$ & 1,056 & 0,988 \\
\hline 870410 & $\begin{array}{l}\text { Dumpers designed for off-highway } \\
\text { use }\end{array}$ & 1,346 & 0,951 \\
\hline 570232 & Of man-made textile material & 0,881 & 0,861 \\
\hline 570242 & Of man-made textile material & 0,745 & 0,587 \\
\hline 870830 & $\begin{array}{l}\text { Brakes and servo-brakes or parts } \\
\text { thereof }\end{array}$ & 1,085 & 0,568 \\
\hline
\end{tabular}

Table 3 exhibits the products for which trade creation is the largest.

Because of the level of disaggregation, trade creation is rather evenly spread across tariff lines. The products that bear the largest trade creation varied, they include vehicles and parts at $85.75 \%$ of total trade creation, followed by petroleum products and textile material. The findings are similar to the research of Lang (2006) on the impact of an FTA with the EU on ECOWAS countries. The products that bore the highest trade creation in the ECOWAS countries included vehicles and parts, and clothes. Table 4 shows the top 10 most vulnerable products to trade diversion.

The most vulnerable products to trade diversion are imported products from the EU that will now come to South Africa at the expense of more efficient producers outside the FTA.

This information is of great importance to South Africa in their negotiation process. The most sensible products to trade diversion are petroleum products, vehicles and parts. Most of the loss results from these products being part of the FTA as South Africa would be importing from a higher-cost producer within the EU. These findings are in line with the study of Lang (2006) on the ECOWAS-EU-FTA, where most trade diversion loss in ECOWAS was because of fuel and oil products.

\section{Revenue effect}

The elimination of tariffs from EU' imports is shown to harm the South African government revenue. Table 5 shows the top 10 largest losses in South African products revenue after the FTA with the EU.

After the full implementation of the FTA, South Africa would see revenue fall by US $\$ 562$ million. It is important to note that the revenue loss in this study relates to import tariff revenues. The South African government needs to use VAT on the imported products so that the revenue shortfall described would taper off.

Vehicles and parts would account for most of the government revenue loss if South Africa and the EU decide

\begin{tabular}{|c|c|c|}
\hline HS-6 & Description & Trade diversion \\
\hline 271012 & Light oils and preparations & 25734.22 \\
\hline 870323 & $\begin{array}{l}\text { Of a cylinder capacity exceeding } 1500 \mathrm{cc} \text { but not } \\
\text { exceeding } 3000 \mathrm{cc}\end{array}$ & 10545.466 \\
\hline 870322 & $\begin{array}{l}\text { Of a cylinder capacity exceeding } 1000 \mathrm{cc} \text { but not } \\
\text { exceeding } 1500 \mathrm{cc}\end{array}$ & 9241.189 \\
\hline 842199 & Other & 4158.194 \\
\hline 870332 & $\begin{array}{l}\text { Of a cylinder capacity exceeding } 1500 \mathrm{cc} \text { but not } \\
\text { exceeding } 2500 \mathrm{cc}\end{array}$ & 1278.69 \\
\hline 870830 & Brakes and servo-brakes; or parts thereof & 1215.07 \\
\hline 870893 & Clutches or parts thereof & 724.904 \\
\hline 870894 & $\begin{array}{l}\text { Steering wheels, steering columns and steering } \\
\text { boxes, or parts thereof }\end{array}$ & 444.452 \\
\hline 870850 & $\begin{array}{l}\text { Drive-axles with differential and non-driving axles, } \\
\text { or parts thereof }\end{array}$ & 392.154 \\
\hline 870870 & Road wheels and parts and accessories thereof & 203.401 \\
\hline
\end{tabular}


to embark on an FTA. Petroleum products also have the second most important impact on government revenue loss. This result is confirmed by the study of Mugano 2013, which found that motor vehicles contributed to major loss in revenue in the Zimbabwe-EU-FTA. South Africa would also need assistance from the EU in building a new fiscal system to replace the budget revenue loss incurred after the FTA. South Africa could also consider lowering the tariffs on EU imports in a gradual way so as to soften the fall in revenue.

\section{Welfare implications}

The concepts of producer and consumer surplus help economists to make welfare (normative) judgements about different ways of producing and distributing goods. The WITS model can only estimate the possible consumer surplus. The major argument in favour of free trade is that consumers benefit from lower prices. This occurs only if trade creation is greater than trade diversion. In the EUSouth Africa FTA, trade creation is greater than trade diversion. Therefore, consumers would benefit from the implementation of the FTA. Although this agreement

TABLE 5: Top 10 largest losses in South African products revenue after the Free Trade Agreement with the European Union (US\$ 000).

\begin{tabular}{|c|c|c|c|}
\hline HS-6 & Product description & Revenue loss & $\%$ of total loss \\
\hline 870323 & $\begin{array}{l}\text { Of a cylinder capacity exceeding } \\
1500 \mathrm{cc} \text { but less than } 3000 \mathrm{cc}\end{array}$ & -130915 & 23.28 \\
\hline 870332 & $\begin{array}{l}\text { Of a cylinder capacity exceeding } \\
1500 \mathrm{cc} \text { but less than } 2500 \mathrm{cc}\end{array}$ & -68252 & 12.14 \\
\hline 271012 & Lights oils and preparations & -49939 & 8.88 \\
\hline 870333 & $\begin{array}{l}\text { Of a cylinder capacity exceeding } \\
2500 \mathrm{cc}\end{array}$ & -46254.5 & 8.22 \\
\hline 870322 & $\begin{array}{l}\text { Of a cylinder capacity exceeding } \\
1000 \mathrm{cc} \text { but not exceeding } 1500 \mathrm{cc}\end{array}$ & -40555.9 & 7.21 \\
\hline 870324 & $\begin{array}{l}\text { Of a cylinder capacity exceeding } \\
3000 \mathrm{cc}\end{array}$ & -39963.1 & 7.10 \\
\hline 870829 & Other & -20657.1 & 3.67 \\
\hline 870421 & GVW not exceeding 5 tons & -18170.6 & 3.23 \\
\hline 401110 & Of a kind used on motor cars & -13241.6 & 2.35 \\
\hline 401120 & Of a kind used on buses or lorries & -12851.6 & 2.28 \\
\hline Other & - & -134552.2 & 23.93 \\
\hline Total & - & -562111 & 100 \\
\hline
\end{tabular}

TABLE 6: Top 10 products with largest consumer welfare after the Free Trade Agreement with the European Union (US\$000).

\begin{tabular}{llll}
\hline HS-6 & Product description & Welfare & $\begin{array}{l}\text { \% of total } \\
\text { welfare }\end{array}$ \\
\hline 870332 & $\begin{array}{l}\text { Of a cylinder capacity exceeding } 1500 \text { cc } \\
\text { but not exceeding } 2500 \text { cc }\end{array}$ & 78703.52 & 58.53 \\
\hline 870323 & $\begin{array}{l}\text { Of a cylinder capacity exceeding } 1500 \text { cc } \\
\text { but not exceeding } 3000 \text { cc }\end{array}$ & 13856.52 & 10.30 \\
870333 & Of a cylinder capacity exceeding 2500 cc & 7199.481 & 5.35 \\
870324 & Of a cylinder capacity exceeding 3000 cc & 4597.256 & 3.41 \\
870331 & $\begin{array}{l}\text { Of a cylinder capacity not exceeding } \\
\text { 1500 cc }\end{array}$ & 2841.658 & 2.11 \\
\hline 870322 & Of a cylinder capacity exceeding 1000 cc & 2051.438 & 1.52 \\
\hline 870421 & but not exceeding 1500 cc & 1144.51 & 0.85 \\
\hline 271012 & LVW not exceeding 5 tonnes & 1108.657 & 0.82 \\
\hline 401110 & Of a kind used in motor cars & 1011.28 & 0.75 \\
\hline 570320 & Of nylon or other polyamides & 908.655 & 0.67 \\
\hline- & Others & 21027.625 & 15.63 \\
\hline Total & - & $\mathbf{1 3 4 4 5 0 . 6}$ & $\mathbf{1 0 0}$ \\
\hline
\end{tabular}

would lead to government revenue loss and have a negative impact on some producers, individual households would benefit from the lower prices. Individuals would be in a position to increase consumption, and therefore, welfare would also increase. Table 6 shows the top 10 products with largest consumer welfare after the FTA with the EU.

After full liberalisation, South African consumers would be able to purchase EU goods at cheaper prices, thus obtaining an improvement in their standard of living. Total consumer surplus in South Africa would be estimated at US\$ 134.45 million. It is assumed that EU exporters and South African importers would pass the benefit of tariff reduction to South African consumers because if they do not do so, consumer welfare would not improve.

The impact of full liberalisation on South Africa would lead to consumer surplus of US\$ 134.45 million. The group of products yielding the highest welfare gains are vehicles (82.82\%) followed by oil (0.82\%). Lang (2006) also found that vehicles were the group of products that led to the highest welfare gain in the EU-ECOWAS FTA.

\section{The impact of European Union Free Trade Agreement on South Africa exports}

Trade liberalisation provides market access beyond their boundaries to participating member states. The EU represents a ready market for South Africa. Has South Africa been able to increase exports in the EU-FTA? This is one of the research question answered in this study.

Using the WITS-SMART model, exporter's point of view is to evaluate whether South Africa has been able to increase its exports after the implementation of the EUFTA. Table 7 shows the impact of the EU-FTA on South Africa exports.

South Africa exports are expected to increase by US $\$ 33.37$ million after the EU-FTA. However, it is important to look at the impact of exports on the individual EU countries. Table 8 shows the increase in exports of individual EU countries.

For negotiation purposes, it is interesting to look at how the EU countries would benefit from the FTA with South Africa. The positive gain is not necessarily in all 28 EU countries. Some countries such as the United Kingdom and Portugal are negatively affected. This could be explained by the fact that the liberalisation schedule has reached its final stage, and other countries such as Poland and Cyprus took advantage of the more open South African market. However, the 28 EU countries as a

TABLE 7: Impact of the European Union Free Trade Agreement on South Africa exports (US\$1000)

\begin{tabular}{llll}
\hline Partner countries & $\begin{array}{l}\text { Exports } \\
\text { before FTA }\end{array}$ & $\begin{array}{l}\text { Exports } \\
\text { after FTA }\end{array}$ & $\begin{array}{l}\text { Exports change in } \\
\text { revenue }\end{array}$ \\
\hline European Union & 12837769.42 & 12871145.65 & 33376.231 \\
\hline
\end{tabular}

FTA, Free Trade Agreement. 
TABLE 8: Increase in exports of individual European Union countries after Free Trade Agreement with South Africa (US\$1000).

\begin{tabular}{|c|c|c|c|}
\hline Partner countries & $\begin{array}{l}\text { Exports } \\
\text { before FTA }\end{array}$ & $\begin{array}{l}\text { Exports } \\
\text { after FTA }\end{array}$ & $\begin{array}{l}\text { Exports change in } \\
\text { revenue }\end{array}$ \\
\hline United Kingdom & 7170726 & 7109943 & -60782.7 \\
\hline Finland & 2411102 & 2469975 & 58872.75 \\
\hline Sweden & 911766.4 & 911236.2 & -530.163 \\
\hline Portugal & 458756 & 457442.1 & -1314.08 \\
\hline Cyprus & 429929.8 & 434635.4 & 4705626 \\
\hline Ireland & 319886.1 & 319717.7 & -168.411 \\
\hline Czech Republic & 291261.8 & 292136.6 & 874.812 \\
\hline Germany & 233369.1 & 233366.4 & -2.694 \\
\hline Romania & 178403.9 & 178310.8 & -93.17 \\
\hline Poland & 141506.5 & 150123.3 & 8616.788 \\
\hline Norway & 138146.6 & 136953.1 & -1193.5 \\
\hline Slovak Republic & 49866.89 & 51573.54 & 1706.654 \\
\hline Lithuania & 45012.4 & 47114.89 & 2102.491 \\
\hline The Netherlands & 37928.06 & 37928.05 & -0.007 \\
\hline Spain & 22955.97 & 22607.7 & -348.278 \\
\hline Estonia & 13072.91 & 13072.51 & -0.399 \\
\hline Hungary & 9498.173 & 9498.048 & -0.125 \\
\hline Luxembourg & 4804.863 & 4803.628 & -1.235 \\
\hline Latvia & 2731.723 & 2722.333 & -9.39 \\
\hline Croatia & 1963.009 & 1963.891 & -0.118 \\
\hline Switzerland & 813.817 & 799.908 & -13.909 \\
\hline Denmark & 735.012 & 734.629 & -0.383 \\
\hline Slovenia & 342.646 & 342.646 & 0 \\
\hline France & 160.54 & 160.54 & 0 \\
\hline Malta & 97.324 & 97.064 & -0.26 \\
\hline Belgium & 66.329 & 66.316 & -0.013 \\
\hline Italy & 26.814 & 26.682 & -0.132 \\
\hline Greece & 0.784 & 0.784 & 0 \\
\hline
\end{tabular}

FTA, Free Trade Agreement.

whole could gain more than US\$ 12 billion in exports revenue after the FTA.

Such information might be of interest to South Africa in order to identify which EU countries could have the greatest stake in negotiating the EU-South Africa FTA. These EU countries would have a decisive role in the negotiation process and might be reluctant to implement full liberalisation.

The total increase in exports remains very low for the EU, with only US\$ 12.4 million compared with the overall exports from South Africa to the EU of US\$ 12.88 billion. This result is confirmed by the study of Lang (2006), which found that the importance of increased exports for the EU countries remained very limited after the EU-ECOWAS FTA. Countries such as the United Kingdom for instance would see exports decline by US\$ 60.78 million in an FTA with South Africa.

\section{The impact of European Union Free Trade Agreement on South Africa imports (US\$ 1000)}

Based on Smart simulation, South Africa is expected to record an increase of US\$ 1.266 billion, which is merely of trade creation effect. Table 9 shows South Africa imports before the EU-FTA, imports after the EU-FTA and changes in imports revenue.
TABLE 9: The impact of European Union Free Trade Agreement on South Africa imports (US\$1000).

\begin{tabular}{llll}
\hline Partner countries & $\begin{array}{l}\text { Imports } \\
\text { before FTA }\end{array}$ & $\begin{array}{l}\text { Imports } \\
\text { after FTA }\end{array}$ & $\begin{array}{l}\text { Changes in imports } \\
\text { revenue }\end{array}$ \\
\hline European Union & 92943855 & 94209969 & 1266114 \\
\hline
\end{tabular}

FTA, Free Trade Agreement.

TABLE 10: South Africa's top 10 imports from the European Union Free Trade Agreement (US\$1000).

\begin{tabular}{lll}
\hline HS-6 & Product description & Value \\
\hline 270900 & $\begin{array}{l}\text { Petroleum oils and oils obtained from } \\
\text { bituminous minerals, crude }\end{array}$ & 15757526 \\
\hline 271012 & Light oils and preparations & 5828044 \\
840681 & Of an output exceeding 40 MW & 896216.4 \\
870410 & Dumpers designed for off-highway use & 839294.8 \\
100630 & $\begin{array}{l}\text { Semi-milled or wholly milled rice, whether } \\
\text { polished or glazed or not }\end{array}$ & 678632.6 \\
\hline 870333 & Of a cylinder capacity exceeding 2500 cc & 653530.3 \\
151190 & Other oil products & 406753.7 \\
852990 & Other electrical machinery equipment & 327228.7 \\
150790 & Other oil products & 227860.5 \\
261690 & Other minerals & 110487.9 \\
Other & Other products not specified above & 11543774.9 \\
South Africa & Imports & 92943855 \\
\hline
\end{tabular}

Using Smart simulations, Table 10 shows the top 10 imports from the EU-FTA (US\$ 1000).

As shown in Table 10, petroleum products, light oils and preparations, vehicles, semi-milled or wholly milled rice, electrical machinery equipment and minerals are the top South Africa imports from the EU-FTA, with an import bill of US\$ 15.75 billion, US\$ 5.82 billion, US\$ 839 million, US\$ 678 million, US\$ 327 million and US\$ 110 million, respectively. The lion's share of these imports comes from the United Kingdom as shown in Table 8.

From an EU total exports perspective, the percentage increase in EU exports in South Africa does not look very important $(1.34 \%)$. However, it is still significant because the actual amount would be about US\$ 1.22 billion.

\section{Sensitivity analysis and robustness tests}

The SMART model does not provide a built-in sensitivity analysis. Also, the uncertainty of the actual values for the Armington market analysis and demand elasticities require rigorous sensitivity to ensure the robustness of the main result presented in this study. The study allows changes in the parameter values (elasticities) in order to test the robustness of the results over a reasonable range as suggested by Mugano (2013). Initially, a base case simulation was run using elasticities from Armington. The researcher had to re-run the simulation under varying assumptions. Lowerand upper bound limits were established for different elasticities. Table 11 shows the robustness and sensitivity analysis of the EU-South Africa FTA on trade creation, revenue welfare, imports and exports.

Reducing elasticity of substitution to 0.5 shows the change in the trade creation from the base case in South Africa. The outcome shows that trade creation 
TABLE 11: Robustness and sensitivity analysis of the European Union-South Africa Free Trade Agreement on trade creation, revenue welfare, imports and exports (US\$ 1000 and $\%$ change).

\begin{tabular}{lllll}
\hline Effects/Indicators & Base case & Lower bound & Upper bound & Worst case \\
\hline Welfare & $134,450.6$ & $136,571.9$ & $133,394.5$ & $125,034.4$ \\
Revenue loss & $-562,111$ & $-513,406$ & $-586,474$ & 782,202 \\
Trade creation & $781,606.42$ & $1,309,524.50$ & $5,805.339$ & 1.049 .806 \\
Imports (\% change) & 1.34 & 1.34 & 1.34 & 0.00016 \\
Exports (\% change) & 0.00096 & 0.0025 & 0.32 \\
\hline
\end{tabular}

increase by $40 \%$ (see Table 11). On the contrary, by increasing elasticity of substitution to 2 and 6 will result in the reduction of the trade creation by $99 \%$ and $98 \%$, respectively. South Africa's total change in imports remains the same in value, although its composition changes as economic agents are substituted across various imports.

Reducing the trade elasticity value to 0.5 reduces revenue loss by $8.66 \%$ (see Table 11). Increasing trade elasticities values to 2 and 6 will respectively increase revenue losses by $4.15 \%$ and $28.13 \%$. The resulting deviations from the middle ground are generally significant. Accordingly, the middle ground estimates could be close to potential sizes.

Reducing the trade elasticity value to 0.5 increased welfare gains by $1.55 \%$. By increasing the trade elasticity value to 2 and 6, welfare gains will respectively reduce by $0.78 \%$ and $7 \%$. Although the margin of error is slightly higher than $10 \%$ in the lower bound limit, the worst-case scenario is that the deviation of welfare gains from the base result is sensible and significant (see Table 11). Accordingly, the middle ground estimates could approximate potential sizes.

Reducing the trade elasticity value to 0.5 is expected to cause an increase in exports by $0.0025 \%$ from base case, (see Table 11). Increasing the trade elasticity value to 2 will decrease exports by 0.00016 . Increasing trade elasticity to 6 will increase exports by $82 \%$. The resulting deviations from the middle ground results are generally significant. Accordingly, the middle ground estimates could resemble potential sizes.

Reducing the trade elasticity value to 0.5 shows no change in imports from the base case (see Table 11). South Africa's total change in imports remains the same in value although its composition changes as economic agents are substituted across various imports.

\section{Conclusion and policy options}

The partial equilibrium simulation with disaggregated trade data for 2012 showed that imports from the EU to South Africa would increase by approximately US\$ 1.27 billion. Although the intention of the EU-South Africa FTA was to expand trade, it did not significantly create more trade between its members. This is in line with the findings on export data that reveal a reduction of trade volumes between South Africa and some European countries such as the United Kingdom.
The EU-South Africa FTA would result in both trade creation and trade expansion effects. Trade creation effects represent $75.44 \%$ of the overall trade effect, largely exceeding trade diversion effects. Trade creation is spread across a large variety of goods though some concentrations are on groups of products such as vehicles and parts, oil products and textile material. Trade diversion effects seem relatively significant $(24.56 \%)$, which is almost $25 \%$ of the whole trade effect. Hence, South Africa has to take these particular products into account during the EU-South Africa FTA negotiation.

In terms of government revenue, the removal of tariff barriers would result in a government revenue loss of US\$ 562.11 million and a welfare gain of US\$ 134.45 million. It appears that consumer surplus would be largely improved by the lowering of the prices of cars and machines.

From the study, it is clear that although the EU-South Africa FTA may have some negative effects on South Africa's economy, it would be welfare improving. The revenue loss and trade creation are potential threats. However, the welfare gain is significant for South Africa. The following policy recommendations can be drawn from the study.

In order to mitigate revenue loss, South African government may need to consider domestic consumption tax such as excises on particular goods and general sales tax such as VAT. The basic argument behind this principle consists of matching each $1 \%$ point reduction in the tariff rate on some final consumption goods with a one point increase in the corresponding domestic tax in consumption on that same good. This will preserve the efficiency gain from the tariff cut because South African consumers will now pay a price that is closer to those in the world market. Also, the government's total tax revenue will go up because these revenues are now collected on all consumption.

The increase in government revenue could, in turn, be used as subsidies or targeted tax incentives to support the transition of those sectors that stand to lose from trade liberalisation such as light oil and other vehicle parts.

The government might seek assistance from the EU in finding a way to reduce the revenue loss. Oil products, cars and parts are the main products that would create the most trade diversion. These products would generate the major revenue losses to South Africa, and hence, the tariff liberalisation on these products need to be implemented in a progressive manner to soften the loss in tariff revenue. These measures would improve welfare in South Africa. 
A limitation of PEM used in this study is that it is static in nature, allowing only for a comparative static comparison of pre- and post-policy change, when all the other variables are held constant which is an oversimplification of the real world. Thus, they ignore the second-round effects, as these models do not consider impacts of policy reforms on the wider economy, as well as intersectoral implications and exchange rate effects.

Dynamic linkages and market feedbacks can be captured in GE models. Therefore, exploring the impact of trade liberalisation between the EU and South Africa on employment and inflation using the GE model should be an important avenue for future research, and help with more precise policy prescriptions for South Africa.

\section{Ethical consideration}

The research is independent and the results are based on the model simulation. The research is therefore impartial.

\section{Acknowledgements}

The author would like to acknowledge with gratitude the support provided by his supervisors Dr G. Mugano and Prof. P. Le Roux. He would also like to include a special note to the Department of Economics of the Nelson Mandela Metropolitan University for their invaluable support. The research was supported by the research capacity of development (RCD) of the Nelson Mandela Metropolitan University.

\section{Competing interests}

The authors declare that they have no financial or personal relationship(s) that may have inappropriately influenced them in writing this article.

\section{Authors' contributions}

K.M.A.G. examined the literature review of the study; identified potential gap that needed to be filled to enhance the knowledge base for the field of study and conducted the analysis and interpreted the results. He also critically commented and provided a thorough conclusion for the results observed. G.M. provided advice and guidance throughout the completion of the research. He advised on how to use the model and to test the robustness of the results. He also assisted in the manuscript correction. P.l.R. provided advice on the flow of the work. He also provided guideline on some of the comments in the article.

\section{References}

Abdelmalki, L., Sandretto, S.M. \& Jallab, S., 2007, 'The free trade agreement between the United States and Morocco: The importance of a gradual and assymetric agreement', Journal of Economic Integration 22(4), 852-887, viewed 06 July 2017 from https://halshs.archives-ouvertes.fr/halshs-00142503/document

Assarson, J., 2005, 'The impacts of the European Union-South Africa Free Trade Agreement', D-Level thesis, Uppsala University.

Baldwin, R., 2011, Preferential trade agreement and multilateral liberalization viewed 01 April 2014, from http://www.sitesourcesworldbank.org/intranettrade/ resources/C6.pdf
Burges, S., 2007, Economic integration, viewed 01 May 2014, from http://www. britannica.com/ebchecked/topic/178433/economic-integration

Choudhry, S., Kalumnal, M. \& Varma, S., 2013, Trade creation and trade diversion in the India Sri-Lanka Free Trade Agreement-A sector specific analysis, Workin paper CS/WP/200/11, Centre of WTO Studies, Indian Institute of Foreign Trade viewed 06 July 2017, from http://www.wtocentre.iift.ac.in/workingpaper/ working\%20paper\%2011.pdf

Department of Foreign Affairs, 2009, SA-EU Strategic Partnership, viewed 10 May 2014, from http://www.dfa.gov.za/foreign/saeubilateral/tdca.html

Department of National Treasury, 2017a, Budget review, viewed 02 June 2017, from www.treasury.gov.za/documents/national\%20budget/2017/review/FullBR.pdf

Department of National Treasury, 2017b, Update on South's Africa trade negotiations, viewed 06 June 2017, from https://www.thedti.gov.za/parliament/2017/Trade_ Negotiations.pdf

Elebehri, A. \& Hertel, T., 2004, A comparative analysis of the EU-Morocco FTA vs. Multilateral liberalization, GTAP Working Paper No. 30, Washington, DC vs. Multilateral liberalization, GTAP Working Paper No. 30, Washington, DC,
viewed 06 July 2017, from http://docs.lib.purdue.edu/cgi/viewcontent. viewed 06 July 2017, from
cgi?article $=1029 \&$ context=gtapwp

European Commission Act, 2004, Trade, Development and Cooperation Agreement (TDCA), viewed 06 April 2014, from http://www.europa.eu/legislation summaries/development/south_africa/r12201_en.htm European Commission Council, 2006, South Africa and the EU, viewed 06 July 2017,
from https://eeas.europa.eu/headquarters/headquartershomepage en/730/ South $\% 20$ Africa $\% 20$ and $\% 20$ the $\% 20$ EU

Industrial Development Corporation, 2013, South African economy: An overview of key trends since 1994, viewed 20 June 2017, from https://www.idc.co.za/... IDC $\% 20$ R\& $\%$ 20publication $\% 20-\% 200$ verview $\% 20$ of $\% 20 \mathrm{k}$

International Monetary Fund, 2003, Changing customs. Challenges and strategies for the reform of customs administration, International Monetary Fund Washington, DC.

International Monetary Fund, 2011, Revenue mobilisation in developing countries, Washington, DC, viewed 20 April 2014, from https://www.imf.org/external/np/ pp/eng/2011/030811.pdf

International Monetary Fund, 2016, IMF Country Report no 16/217, South Africa Article IV Consultation, Washington, DC.

Kwaramba, M., Kwenda-Magejo, P. \& Rankin, N., 2015, The European Union- South Africa Free Trade Agreement and exports trade margins, viewed 20 June 2017, from http://www.2015.essa.org.za/fullpaper/essa_2898.pdf

Lang, R., 2006, A partial equilibrium analysis of the impact of the ECOWAS-EU, Economic Partnership Agreement, United Nations Economic Commission for Africa, viewed 06 July 2017, from https://www.gtap.agecon.purdue.edu/ resources/download/2728.pdf

McLaren, J., 2004, Free Trade Agreement, Custom Union and the dynamics of political influence, viewed 06 April 2014, from http://www.people.virginia.edu/.../FTAs CUs_and_the_dynamics_of_political_influence

Milner, L., Morrissey, O. \& McKay, A., 2005, 'Some simple analytics of the trade and welfare effects of economic partnership agreements', Journal of African Economies 14(3), 327-358. https://doi.org/10.1093/jae/eji006

Mkenda, B. \& Hangi, M., 2009, Revenue implications of EPA on Tanzania, viewed 06 April 2014, from http://www.cuts-geneva.org/.../BIEAC-Revenue_implications of the_EC-EAC_E

Mugano, G., 2013, 'The impact of trade liberalization on Zimbabwe', PhD thesis, Nelson Mandela Metropolitan University.

Mugano, G., Brookes, M. \& Le Roux, P., 2013, 'Estimating the impact of a COMESA Customs Union on Zimbabwe using a Tariff Reform Impact Simulation tool (TRIST)', African Journal of Business Management 4(10), 104-120.

Othieno, L. \& Shinyekwa, I., 2011, Trade, revenue and welfare effects of the East African Community Custom Union principle of asymmetry on Uganda: An application of Wits-Smart Simulation Model, Economic Policy Research Centre, viewed 06 July 2017, from https://ageconsearch.tind.io/record/150480/files/ series79.pdf

Peters, G.H., 1979, International trade, investment, and payments, Houghton Mifflin Company, Boston, MA.

South Africa, Department of Trade and Industry (DTI), 2014, Trade statistics, viewed 02 April 2014, from http://www.thedti.gov.za

Stern, R., Francis, J. \& Bruce, S., 1976, Price elasticities in international trade An annotated bibliography, Macmillan Press, London.

Suranovic, S., 1997, International trade theory and policy, viewed 06 April 2014, from http://www.internationalecon.com/trade/Tch110/T110-2A.php

Tsolo, M., 2010, 'The impact of European Union-SA trade development cooperation agreement on Botswana, Lesotho, Namibia and Swaziland', Review of Economic and Business Studies 3(1), 129-148.

UN COMTRADE, 2014, Online database, viewed 20 June 2015, from https://comtrade. un.org/

United States International Trade Commission, 2017, Trans-Pacific Partnership Agreement: Likely impact on the U.S. economy and on specific industry sectors, viewed 02 June 2017, from https://www.usitc.gov/publications/332/pub4607.pdf

Villa, C., Gomez, D. \& Omar, L., 2012, The Colombia-Canada free trade area, viewed 06 April 2014, from http://www.vi.unctad.org/digital-library/?task=dl_doc\&doc_ name $=787$ colombia

World Bank, 2015, Tariff rate-applied-weighted mean-all products (\%) in South Africa viewed 02 June 2017, from http://www.tradingeconomics.com/south-africa/ tariff-rate-applied-weighted-mean-all-products-percent-wb-data.html 